Article

\title{
Lucy Hutchinson and Margaret Cavendish: Civil War and Enemy Commiseration
}

\author{
Yousef Deikna \\ English Department, Idaho State University, Pocatello, ID 83209, USA; deikyous@isu.edu
}

Received: 11 January 2019; Accepted: 19 February 2019; Published: 1 March 2019

\begin{abstract}
Lucy Hutchinson (1620-1681) and Margaret Cavendish (1623-1673), prolific writers from the seventeenth century, came of age in one of the most difficult times in British history. Blair Worden, an eminent historian, writes, "The political upheaval of the mid-seventeenth century has no parallel in English history," and none of the previous conflicts "has been so far-reaching, or has disrupted so many lives for so long, or has so imprinted itself on the nation's memory" $(2009$, p. 1). Hutchinson and her husband, John, were on the side of the parliamentarians in the Civil War while Cavendish and her husband, William, were stout royalists. Instead of showing aggressive stances against their enemies, Hutchinson and Cavendish engaged expansively in a language of empathizing with the enemy in order to lessen the extreme partisanship of that period. Focusing specifically on Hutchinson's Memoirs of the Life of Colonel John Hutchinson, and Cavendish's Sociable Letters, among other writings, I argue that during the political impasse which characterized the English Civil War writings, the perspectives advanced by Hutchinson and Cavendish highlight the valuation of human life regardless of political allegiance, augmenting the odds for peaceful co-existence, in which empathy is foregrounded over, and at times alongside, loss and agony as a result of the Civil War aftermath. Suzanne Keen's groundbreaking research in Empathy and The Novel draws upon examples from the Victorian period to illustrate her understanding of empathy, but she also states that "I feel sure they also pertain to the hopes of authors in earlier periods as well" (2007, p. 142), which is a position taken wholeheartedly in this article. Using a cognitive literary approach where authorial empathic constructions are analyzed, Hutchinson's and Cavendish's closely read texts portray an undeniable level of commiseration with the enemy with the goal of abating violence and increasing cooperation and understanding.
\end{abstract}

Keywords: English Civil War; Lucy Hutchinson; Margaret Cavendish; empathy

During partisan politics of Civil War England, and the dehumanization and vulgarity associated with war rhetoric, Hutchinson's and Cavendish's constructions of empathic scenarios necessarily devised strove to support a world of civility and reasonableness, especially in a polemic atmosphere in which people fought not only with swords and muskets but with "paper, appealing to the nation with indignant ripostes to each other's declarations and messages and protests" (Worden 2009, p. 40). When commiserating with the enemy by helping or advancing their agenda in any way was considered high treason with no less than capital punishment awaiting those involved, yet, over and over again, Hutchinson and Cavendish did invest in writing about the miseries of their people even if they were from the other side of the war, as the examples below will demonstrate. It is worth keeping in mind that at the time, politics and war were polemic subjects though Norbrook (1997) points out that for Hutchinson at least, "the personal and the political are never clearly separable" (p. 470). In her writings, Cavendish too engaged in topics of religion, war, governorship, and other controversial topics, yet she kept mitigating her writings with reader epistles to lessen societal sanctions against feminine expression. Both authors though present empathic constructions of "enemy" situations and characters in order to mitigate anxiety and fear, as well as to lessen violence and increase livability for 
all. More importantly, for Hutchinson and Cavendish as the examples below show, they buttress a vision of civilized English society as one that has built-in social justice even for one's enemies, as it is the one way to progress as a country. Mia Szalavitz and Bruce Perry, well-known scholars of empathy, explain that "Not only will frightening circumstances promote inhumane behavior, they will also tend to minimize intellectual capacity, as the fear that results from being under constant threat remodels the brain" so that "individuals who are always threatened cannot reason to their maximal capacity" (Szalavitz and Perry 2010, p. 116). Hutchinson, though benefiting during the first eight years of the Interregnum as her husband John Hutchinson became one of the leading parliamentarians in the commonwealth, suffered tremendously in the last two years of the Interregnum followed by the Restoration period. They lost their estates, and her husband was first considered highly suspect, and eventually died imprisoned in Sandown Castle, one of the worst prisons at the time in England, indicating how the Hutchinsons fell out of favor during the Restoration period after being high gentry class in the years before and during the Civil War. Similarly, Cavendish's relatives were killed and forced to go to exile during the Civil War. Her brother Charles Lucas was executed and her mother lost her estates and died shortly after feeling the misery of her loss ${ }^{1}$. Cavendish herself fled to exile with Queen Henrietta Maria, serving in her court, even though her family objected to the idea. Under this duress, Hutchinson and Cavendish were in fact able to pen their works, but it was through engaging imaginatively with the trauma their families were experiencing. Martin Hoffman, a long time empathy researcher, argues that "Empathy can thus be aroused when observers imagine victims: when they read about others' misfortunes, when they discuss or argue about economic or political issues, or even when they make Kohlbergian ${ }^{2}$ judgements about hypothetical moral dilemmas" (Hoffman 2000, p. 91).

In the early modern period, there are no defined boundaries of genre. For example, even though Hutchinson's Memoirs of Colonel Hutchinson (hereafter Memoirs) might sound like a historical text with myriad historical events pertinent to the Hutchinsons' lives, it uses a lot of literary characteristics. For example, Susan Cooke argues that the Memoirs should be considered a protonovel, saying, "Her very subjectivity, while perhaps detracting from the value of the Memoirs as a factual document (though on the whole its history is accurate) looks towards the development of the novel, which demands a presentation of a story to an audience, and the communication of one continuum to another" (Cooke 1993, p. 276). Hutchinson's Elegies, discovered by David Norbrook in 1997, uncovers Hutchinson's agency as a writer with a clear personal voice eulogizing her husband's legacy and his attributes in verse. Similarly, Cavendish, the first early modern women writer to publish her work during her life, achieved literary acclaim for her fictional and philosophical writings, including Sociable Letters, which are mostly imaginative correspondence between Cavendish and other characters, though historians have confirmed the reality of some of those addressees.

The relationship between and the civilizing process and the production of written material especially by women of the gentry class and above in the early modern period "saw a significant growth in the rates of female literacy, particularly in the cities" (Barker-Benfield 1992, p. 163), leading to fashioning a feminine expression that highlights new emphatic sensibilities to reform society. What accelerated the civilizing process is the constant questioning of the status of women in society as

1 In summarizing the war aftermath, Cavendish writes in True Relation, "But not only the family I am linked to is ruined, but the family from which I sprung, by these unhappy wars, which ruin my mother lived to see, and then died ... . These unhappy wars forced her out, by reason she and her children were loyal to the King, for which they plundered her and my brothers of all their goods, plate, jewels, money, corn, cattle, and the like, cut down their woods, pulled down their houses, and sequestered them from their lands and livings; but in such misfortunes my mother was of an heroic spirit, in suffering patiently where there is no remedy (Newcastle et al. 2000, pp. 48-49).

2 Lawrence Kohlberg, a preeminent American psychologist whose "six stages of moral development" in light of Jean Piaget's work on morality, sparked an important achievement in the field of moral development. Hoffman, on the other hand, focuses on ways of internalizing empathy in the development of a human being in a society. While both scholars account for ways of how moral behaviors develop, Hoffman's criticism of Kohlbergian theory shadows many similar observations that Kohlbergian theory projects many inconsistencies in terms of how humans form moral judgements, and it is limiting to human diversity of thinking, a point with Hoffman's work opposes, showing humans, instead, capable of reasoning at diverse situations without any contradictions or inconsistencies. 
well as the genesis of women writers in the period, according to Graham Barker-Benfield (1992, p. 278). For this article, Hutchinson and Cavendish are chosen to represent a case where empathy for the other is clearly a distinguishable occurrence as members of warring groups in the Civil War period, who, according to Nigel Wheale, "was the elite which had most to lose in the periods of crisis" (Wheale 2007, p. 25), resulting in anxieties throughout both Hutchinson's and Cavendish's chosen writings; yet, the authors could be empathizing not just to support a peaceful living for all, but they might also be seeing the value of bipartisanship at the time, a quality which is not always present at times of war. This research illuminates the writings of Hutchinson and Cavendish, both of whom created voices that reject tribalism for a more empathic society where reasonable contestations should be heard even if they are against one's ideals.

Recent insights from cognitive science that are relevant to Hutchinson's and Cavendish's writings focus on "empathy's role in pro-social and altruistic behavior" (Coplan and Goldie 2011, p. xxii), which specifically looks at the moral significance of empathy and its ethics of care, which include insights from researchers like Martin Hoffman, Steven Pinker, Amy Coplan, and Peter Goldie, among others. These researchers provide the scientific cognitive material for empathy based on experimental analyses, gaining insights about perspective-taking, which is the ability to feel and think from other points of view; mind-reading, or empathic accuracy, which is the ability to accurately guess someone's mind via physical or language cues; emotional contagion, which is a process of communicating one's feelings and inner emotions to surrounding environment; familiarity bias, which is the human tendency to feel empathy for people similar to oneself and to withhold empathy from those outside one's group; and authorial strategic empathizing, which is instigating readers' empathy through devised situations, among other cognitive processes. For example, Hoffman "highlights the role of empathy in moral emotion, motivation, and behavior" (Hoffman 2000, p. xxv). This emphasis on empathy as an ethic to be valued by all during difficult times resonates with arguments about the civilizing process as described by Norbert Elias, Steven Pinker, and Keith Thomas. Despite differences, these scholars argue that the civilizing process such as the increased practice of perspective-taking through the increased literacy rates gradually decreased violence and increased the value of, trade, tolerance, just practices, and human cooperation. The civilizing process is not linear, and rather went through different setbacks; nevertheless, the process hascontinued till this very day. Norbrook points out many instances in the Memoirs where Hutchinson is engaged in scathing attacks against those who used their wit in a way that frustrated the cause of the parliamentarians like Dr. Huntingdon Plumtre (Hutchinson and Keeble 1995, p. 96) and James Chadwick (ibid., 1994, p. 97). In both cases, these vicious attacks on these characters were unavoidable as they violated civil conduct of breaching trust given to them by her husband, and the parliamentarians in general. Hutchinson cannot be considered for advancing feminist ideals, where in her Memoirs, she projects herself as subservient to her husband's. Likewise, Deborah Boyle argues that Cavendish sees the absolutism of the King as "necessary to promote peace, it seems reasonable to infer that she thought Patriarchal marriage was also necessary to promote peace", which dislodges the parliamentarian strife for limiting the powers of the monarchy (Boyle 2013, p. 528).

Of particular importance is the involvement of Hutchinson and Cavendish with the public sphere, which is a key part of the civilizing process. The steady increase in reading practices, especially for women noticeably starting from the 1650s and dramatically increasing by the 1700s in England (Pinker 2012, p. 174), greatly increased the consumption of perspective-taking, and accepting of others' viewpoints. Pinker rightly argues that, "the cognitive process of perspective-taking and the emotion of sympathy must figure in the explanation for many historical reductions in violence," pointing out that empathy cannot be the only solution to world problems, and it has to be accompanied by institutional reforms to take an effect (Pinker 2012, pp. 590-92). Still, to see these writers engage in empathic manifestations sheds new light on the development of nobler sensibilities during the seventeenth century. 
Although Hutchinson is a republican and Cavendish is a royalist, both showed empathy and concern for the other warring group, promoting understanding and peace. News pamphlets and petitions calling for specific declarations proliferated dramatically during the Civil War period corresponding with an uptick of printing houses (Pinker 2012, pp. 172-75). For women writers in the early modern period, the changing patterns of work, according to Graham Barker-Benfield, "allowed more women to find more time for literacy in the seventeenth and eighteenth centuries, and therefore, with women's ability to leave the historian a record of their wishes on an unprecedented scale, albeit one still largely confined to the bourgeoisie" (Barker-Benfield 1992, p. 161).

Sarah Ross stresses that for women who circulated their work for readership in manuscript form starting from the sixteenth century with Elizabeth Melville, Anne Southwell, and concluding with the latter part of the seventeenth century with Jane Cavendish, Putler Hester, and Lucy Hutchinson, all of whom "engaged in unique and particular social, ideological, and geographical networks defined not by gender but by family, community, and religious and political affiliation." Ross sees a continuum of early modern women writing "in the sense that clear commonalities can be identified in the poetic tropes, genres, and material forms in which they articulate their politics" (Ross 2015, p. 6). Manuscript networks offered Putler and Hutchinson a venue "in which they were active participants who were vital to seventeenth century literary production, and were potent literary and socio-political arenas, continuing to flourish into the first half of the eighteenth century" (Ross 2015, p. 23). Even if Hutchison has not published her work during her life time, the circulation of the material in manuscript form indicated a certain type of readership acknowledged during the period.

Empathy has long occupied English literary consciousness. T.S. Eliot famously said in 1921 that "the dissociation of sensibility" he experienced when comparing early seventeenth-century poetry with latter periods leads one to "look into the cerebral cortex, the nervous system, and the digestive tracts" (p. 250 qtd in Keen 2007, p. 57) in the poetic lines, and he especially valued the empathic connection that these poets create between themselves and their readers (Keen 2007, p. 57). Empathy came under renewed investigation recently especially in the literary domain. Coplan and Goldie (2011) identify empathy as "a complex imaginative process in which an observer simulates another person's situated psychological states (both imaginative and affective) while maintaining clear self-other differentiation" (p. xxxiv). Or as Martin Hoffman puts it, "empathy is the cognitive awareness of another person's internal states, that is, his thoughts, feelings, perceptions, and intentions" (Hoffman 2000, p. 29). Empathy is more noteworthy in conditions where those mentioned are not relatives, but strangers who do not belong to the same ideological group. There have been many studies of empathy that focus on the theory of mind, which is "our ability to recognize others' mental states as different from our own and to understand their beliefs, desires, and intentions" (Jaén and Simon 2013, p. 20). This later develops further into what is called "simulation theory", which affirms that readers of literary texts, especially novels, tend "to replicate, mimic, or impersonate the mental life of the target agent" either in a real life story or an imaginative fictional one (Gallese and Goldman qtd. in Jaén and Simon 2013, p. 21).

Such learned experience could be transferred to real-life situations originating from the connection created with the emotions of the literary characters (ibid., p. 21). Thus, this emphasis on empathy helps critics understand literature both at the individual or ontogenetic level and at the species evolution or the phylogenetic level (ibid., p. 21). Jaén and Simon further state that empathy is essential in understanding affective responses to literary readings, and could offer answers to why readers cry or laugh when deeply immersed in the act of reading. Stories learned from a literary work could be seen as an adaptive mechanism of survival where readers could learn valuable lessons about life without endangering themselves (ibid., p. 21), boosting readers' mental functions of empathizing via the intermental thinking of the other (Jaén and Simon 2013, p. 22). This could explain why people today, who are way more literate than people in the Renaissance, are more sensitive to violence in all of its forms. It is this development of intermental thinking that drives people into standing up for those who are in need of help. 
Now turning to works of Cavendish that employ empathy, in Sociable Letters, specifically Letter 16, Cavendish offers a compelling empathy inducing language for those who differ from her own politics. She says,

I Hope I have given the Lady D.A. no cause to believe I am not her Friend; for though she hath been of Ps. And I of Ks. Side, yet I know no reason why that should make a difference betwixt us, as to make us Enemies, no more than cases of Conscience in Religion, for one may be my very good friend, and yet not of my opinion ... (Newcastle and Fitzmaurice 2012, p. 60)

The empathic accuracy that Cavendish shows to addressed friend who has a republican ideology foregrounds the need for human cooperation across partisan ideological boundaries. In fact, the above instance of empathy happens in more than one fictional letter that Cavendish composed. In Letter 9 , she clearly states that women should not interfere in politics of the country as they cause Civil Wars. This is an important letter as Hutchinson and other republicans accuse Charles I's queen Henrietta Maria of promoting her own politics in England. Hutchinson, in her Memoirs, calls Charles I an uxorious husband, who does not know how to control his country as his letters that the parliamentarians uncovered show (Hutchinson and Keeble 1995, p. 200). Ann Hughes, however, indicates that Hutchinson's evaluation of the King as too effeminate to rule the country, and succumbing to his wife's demands instead of his country, is a common allegation against the royalists as Parliamentarians see that a family matter in the King's house is spewing out of control and affecting the whole country (Hughes 2012, pp. 61-62). Nonetheless, Cavendish's opinion that political partisanship should not confine people's lives is a significant advancement in the way people imagined their political allegiance at the time. She compares politics with matters of religion, which is personal between the individual and God, and could only be judged by God himself. Cavendish acquiring this position on republicans as a royalist herself clearly identifies an act of empathy to the other side of the war and to acquire their position even fictionally will create an atmosphere of altruism and peace as Pinker indicated (Pinker 2012, p. 590).

Yet in Letter 120, Cavendish furthers her opposition to violence in general without pointing fingers. She states, "for in a Civil War, Brothers against Brothers, Fathers against Sons, and Sons against Fathers, become Enemies, and Spill each others Blood, Triumphing on their Graves" (Newcastle and Fitzmaurice 2012, p. 174). Like the previous letter, the loss of the war is inflicted on everybody, not just her side. In fact, Cavendish goes on to give her own theory of what drives violence. It is a "Fever of Fury, or a Furious Fever of Cruelty ... the Plague of the Mind" (ibid., 2012, p. 174). Cavendish's view of the situation of an individual who engages in unjustified violence is similar to Hoffman's hot cognition where the emotional side of the brain takes over, thus leading a human being into acts of irrationality. The drive to this continuous violence in her view is something deeply seated in the minds of those who continue the violence from either side. In cognitive terms, the identification and experience of war that she had been through enabled her to see all of the causes of the mayhem, especially when she admits that "Unwise Government, where many Errours gather into a Mass" (ibid., 2012, p. 175), among other causes she proposes for why wars start. Katie Whitaker, Cavendish's biographer, stresses that in many of her writings, Cavendish "envisaged groups of people gathering to read her plays aloud and discuss the choices and actions and the moral and intellectual issues presented" (Whitaker 2003, p. 211). In an epistle to The Blazing World, for example, Cavendish contemplates why fictions are important for human beings. It is important to "recreate the mind, and withdraw it from its more serious contemplation" (Newcastle and Lilley 1994, p. 124), and she hopes that no one will blame her for this art creation because "it is in every one's power to do the like" (1994, p. 124). As Sara Mendelson reminds us, Renaissance women writers have to be both modest and reserved, but also leaders in mainstreaming civil manners (Mendelson 2000, p. 117). Thus, Cavendish could be both a moralizer and modest woman, yet at the same time making a paragon of reasonableness and justice through her special royalism. Jacqueline Broad and Karen Green stress that "Cavendish's political thought is a critical response to the horrors of civil war, and her central 
problem is how to secure the obedience of subjects and maintain peace and order in civil society" (Broad and Green 2009, p. 200).

Other instances highlight empathizing with the poor as the real noble people, e.g., Letter 55, various tragic issues faced by married women, e.g., The Convent of Pleasure act III scene II to X, and other instances of empathy inducing situations that are designed to invoke empathic distress on the readers. All such instances represent what Barker-Benfield calls the "new emphasis on sensation and feeling as the true basis for a claim to moral consideration" (Barker-Benfield 1992, p. 231) during the seventeenth century.

Now moving to Hutchinson's Memoirs is similarly rife with examples of empathy. Hutchinson indicates how royalist close relatives helped her husband while in regicide trial after the Restoration like Sir Richard Biron and Allen Apsley, who both fought as captains in the Royalist army in the battle of Edgehill (Hutchinson and Keeble 1995, p. 282). However, the list of royalists who stood by his side in court includes others who were stout enemies during the war, like the Duke of Newcastle-William Cavendish who acted humanely with the Colonel and was really an important point of contact in the royalist side whom Hutchinson is really grateful for (Hutchinson and Keeble 1995, pp. 300-2). Whenever Hutchinson mentions William Cavendish, the information is objective even in her narration of his involvement in the Civil War, and the intimacy towards him increases after the Restoration as Cavendish was reinstated to some of his previous positions held in the North of England where the Hutchinsons now live. In one instance, Hutchinson narrates that her husband was being fetched, for new accusations of plotting against the King, to talk to "the Marquess of Newcastle, who treated him very honourably; and then falling into discourse with him, 'Colonel,' saith he, 'they say you desire to know your accusers, which is more than I know'" (Hutchinson and Keeble 1995, p. 300). Even with the seriousness of the accusation, Hutchinson is left alone to leave his property without guards as per orders from Cavendish. What is apparent from Hutchinson narrations of Cavendish is civility shown to her husband from this royalist neighbor who was also in exile and his estates confiscated and sold during the Interregnum. Hutchinson sees that empathy towards her husband here is a natural right afforded to them by their equal empathic treatment of royalists in the war years. Other royalists like Mr. Palmer, Sir George Booth, came to testify positively on behalf of her husband in court. Hutchinson states "Although they knew his principle contrary to theirs, yet they so justified his clear upright carriage, according to his own persuasion, as was a record much advancing his honour, and such as no man else in that day received" (Hutchinson and Keeble 1995, p. 282). This instance paints a picture of a true Independent who does not depend on court connections to support his cause even though they disagree with him at the ideological level. Mia Szalavitz and Bruce Perry tell us that if one's kin are involved in a dangerous situation, it could impact one's nervous system negatively, as it is wired in human brains and genetics to feel with kin (Szalavitz and Perry 2010, p. 14), but the example of those men standing up for the Colonel in trial is possible through a social bonding similar to what Pinker calls "communal relationships" that results in "mutual sympathy" (Pinker 2012, p. 585) as both Hutchinsons see positivity from those royalists. These unexpected allies must also have experienced something positive from the Hutchinsons in the past. It is one of the most remarkable kinds of empathy: perspective-taking to minimize conflict based on mutual respect.

Another great example of empathy is to be found early on in the Memoirs, where she mentions how her husband, once appointed as the commissioner from the high court of the Parliament, prevented royalist prisoners accused by the court from facing persecution as he thinks that it is enough that those in high positions faced the penalty. Hutchinson says, "His unbloody nature desiring to spare the rest of the delinquents after the highest had suffered, and not delighting in the death of men when they could live without cruelty to better men" (Hutchinson and Keeble 1995, p. 237). These aforementioned lines are repeated over and over throughout the Memoirs, where Hutchinson sees that most of those in the lower ranks who joined either side in the conflict were driven by economic reasons to support their families rather than really seeking to support one side over the other for ideological reasons (e.g., Hutchinson and Keeble 1995, pp. 307-8). There are other similar explications of soldiers from lower 
social classes in the Memoirs whom Hutchinson highlights positively as a shared emotional response to the violent conditions in the country. These moments of conveying empathic concerns highlight the Renaissance's turn to prose writings to plainly convey emotions of the role-taking imagination in order to reach out to as many readers as possible (Keen 2007, p. 41).

The Hutchinsons, in fact, were treating royalists well, especially during the Protectorate where Hutchinson and her husband retired from political activities, going back to the countryside after objecting to Cromwell's Protector status, and the dissolution of Parliament. Hutchinson was relieved of his duties in 1653 and was forced out of London after official appointment as a governor to Nottingham Castle in 1643, and sitting in the Counsel of State. Norbrook (2003) indicates that the Hutchinsons during this retirement period enjoyed many activities similar to royalist ones, like collecting paintings, teaching children music and dancing, and translating Lucretius's On the Nature of Things (qtd. in Richards 2003, pp. 72-73). Even the physical appearance of John Hutchinson, a Parliamentarian with long hair, was not appealing to fellow republicans who thought it is not a sign of allegiance to their cause (Bryson 1998, p. 217). In fact, Hutchinson quotes a line from John Cleveland's satire "Hue and Cry" mocking the way the Puritan minsters looked as "something ridiculous to behold" (Hutchinson and Keeble 1995, p. 87). Norbrook indicates that this is an important aspect of the way the Hutchinsons' civility to royalists materialized as they were accused of using a "cavalier like language" by other republican groups (p. 72 qtd. in Richards 2003), indicating how the solidary of these social relations that the Hutchinson's enjoyed cut through divisions caused by ideology (ibid., p. 73). Within- group familiarity bias which should have been directed against royalists is not part of Hutchinson's structure of feeling throughout her narrations of the Civil War incidents where Norbrook sees a general positive trend in the way Hutchinson views royalists.

The last example of empathy comes from Hutchinson's Elegies, where Norbrook indicated that Hutchinson is much more direct and personal in these twenty-three numbered poems (Norbrook 1997, p. 469). In Elegy 4, Hutchinson presents an account of her husband as both a magnificent, stout soldier, and very honorable religious man. She says: "Shuch killing weapons too he wore/Not to destroy but to restore;/Which done he threw ye sword aways/Embraceing Those who prostrate Lay;/" (4.6-10). Though showing mercy for vanquished foes is a heroic trope, it could also be read as:I don't want to be in this person's situation or If I were to be put in this situation like this defeated foe, I would appreciate being set free. Although, it is clear here that the second reading into these lines is stronger from the word choice like "throw ye sword away" and "embracing" it is her husband's civil practices during the unjust war being described here where a word like 'embracing' is an indication of fellow feeling towards friends rather than just heroism to a defeated foe. Similarly in Elegy 5, she states, "He flung his sword \& with it hate away/Releiuing vanquisht foes whoe prostrate lay; Brauely he Armd more brauely he lay armes downe/Thinking it more to win than to weare a Crowne" (5.57-60). Hutchinson in these poems tries to show that her husband's arms were used in a noble way-namely, to protect, and defend himself rather than just acting as a violent perpetrator in the war; although this is a common position to take for those siding with the Parliamentarian forces, it still gives a reason why arms have to be used in the first place (Walters 2013, p. 218). Being involved in the military, as Norbrook comments, was only a regrettable necessity (p. 69 qtd in Richards 2003, p. 69). Further, her husband showed mercy to those enemies who "prostrate Lay," which is repeated twice in these poems. The Colonel's arms too are put down once chance happened to stop the bloodshed, and allow for peace and justice to take effect. The word "bravery" which appears in these poems indicates what Johnathan Barry claims as an important moral development during the seventeenth century as more and more people started to associate civility with "possession of specific cultural attributes" (Barry 2000, p. 196), including highlighting empathic concerns during difficult times. Mannerisms do change from one age to another. For example, Barker-Benfield states that in the seventeenth century, "honor," for example, experienced meaning change from "title of rank" to "goodness of character," which is "a shift corresponding to the evolution of the fluidity of sensational psychology, but corresponding, too, to the promises Protestantism and its sequelae (as well as civic humanism) held for women" 
(Barker-Benfield 1992, p. 289). Civil practices are essential to empathy as they lead the way for a nobler society driven by empathic distress. Patricia Patrick notes how Hutchinson was adamant in treating the wounded royalists even when Captain Palmer vociferously objects to Hutchinson's "favour to the enemies of God," and she responds by saying that she is performing "her duty in humanity to them, as fellow-creatures, not as enemies" (p. 129 qtd. in Patrick 2015, p. 351). This took place at a time when other Parliamentarians were unjust and cruel to the defeated royalists (Hutchinson and Keeble 1995, p. 129). Sympathizing with the victims of the war by helping them heal is an altruistic act to alleviate their suffering whether Hutchinson enjoys it or not regardless of social class, or ideological affiliation of those affected. The motivation behind this act is to promote peace and tranquility as the empathizer does not benefit in any shape or form. Pinker argues that such acts of empathy are necessary even if one does not intentionally believe in doing a certain empathic act (Pinker 2012, p. 584). Hutchinson and Cavendish are undoubtedly participating in a mission to reform men's sensibilities as Barker-Benfield notes, "The culture of sensibility wished to reform men, to make them conscious of women's minds, wishes, interests, and feelings, in sum, their sensibility (Barker-Benfield 1992, p. 249). Hutchinson towards the near end of the Memoirs when her husband in Prison and she was appealing on his behalf in the court, directly states how her discourse enabled her to negotiate a deal for her husband from his jailor at the Tower of London (Hutchinson and Keeble 1995, pp. 307-10). This indicates a discourse sensibility that her husband was not able to make on his own-the ability to forge solutions based on empathic language constructions.

Similarly, Lopes (2011) argues that empathy is always involved with some sort of motivation, and empathy is a skill that could be improved (qtd in Coplan and Goldie 2011, p. 119). Hutchinson and Cavendish deployed empathy on different ways to put brakes on warrior practices like honor culture, and other war-related cultural themes including martial glorification of winning, and other manly virtues that eventually lead to bloodshed and more children becoming orphaned as a result of the conflict (Pinker 2012, pp. 686-87). Early modern women writers therefore, could be understood within the framework of larger civilizing process that allowed for an emphasis on civil discourse. Sarah Ross indicates that there "was 'a major shift' between 1660 and 1750 from women's domestic, devotional, and coterie poetic practice to 'the emergence of the professional woman poet within an expansive print culture" (Ross 2015, p. 3). Clearly Hutchinson is leaving her works for her connections, and possibly she thought of us too reading her work, and she probably thought of teaching us of these empathic moments and how one could benefit from them through empathic contagion that allows one to experience how it feels to be in someone else's position. While Hutchinson wrote the Memoirs to clear her husband's name, it also offers a record of empathy and community beyond political affiliation and the wounds of war.

Funding: This research received no external funding.

Acknowledgments: Special thanks to my advisor Curtis Whitaker for assistance with finding sources and conducting such research on this area. I would also like to thank Matthew VanWinkle for his continuous support in making this work come to light. In addition, my sincere thanks go to the editors of this journal who helped in editing this paper.

Conflicts of Interest: The author declares no conflict of interest.

\section{References}

Barker-Benfield, Graham. 1992. The Culture of Sensibility: Sex and Society in Eighteenth-Century Britain. Chicago: University of Chicago Press.

Barry, Johnathan. 2000. Civility and Civic Culture in Early Modern England: The Meanings of Urban Freedom. In Civil Histories: Essays Presented to Sir Keith Thomas. Edited by Peter Burke, Brian Harrison, Paul Slack and Keith Thomas. Oxford: Oxford University Press.

Boyle, Deborah. 2013. Margaret Cavendish on Gender, Nature, and Freedom. Hypatia: A Journal of Feminist Philosophy 28: 516-32. [CrossRef] 
Broad, Jacqueline, and Karen Green. 2009. Margaret Cavendish, Duchess of Newcastle. In A History of Women's Political Thought in Europe, 1400-1700. Cambridge: Cambridge University Press.

Bryson, Anna. 1998. From Courtesy to Civility: Changing Codes of Conduct in Early Modern England. Oxford: Clarendon Press.

Cooke, Susan. 1993. "The Story I most Particularly Intend": The narrative Style of Lucy Hutchinson. Critical Inquiry 5: 271-7.

Coplan, Amy, and Peter Goldie, eds. 2011. Empathy: Philosophical and Psychological Perspectives. New York: Oxford University Press.

Hoffman, Martin. 2000. Empathy and Moral Development: Implications for Caring and Justice. New York: Cambridge University Press.

Hughes, Ann. 2012. Gender and the English Revolution. London: Routledge.

Hutchinson, Lucy, and Neil H. Keeble. 1995. Memoirs of the Life of Colonel Hutchinson. London: Dent.

Jaén, Isabel, and Julien J. Simon. 2013. Cognitive Literary Studies: Current Themes and New Directions. Austin: University of Texas.

Keen, Suzanne. 2007. Empathy and the Novel. Oxford: Oxford University Press.

Lopes, Dominic. 2011. An Empathic Eye. In Empathy: Philosophical and Psychological Perspectives. Edited by Amy Coplan and Peter Goldie. New York: Oxford University Press.

Mendelson, Sara. 2000. The Civility of Women in Seventeenth-Century England. In Civil Histories. Edited by Brain Harrison Burke and Paul Slack. Oxford: Oxford University Press, pp. 111-25.

Newcastle, Margaret C., and James Fitzmaurice, eds. 2012. Sociable Letters. New York: Routledge.

Newcastle, Margaret C., and Kate Lilley. 1994. The Description of the New Blazing World and Other Writings. New York: Penguin Group.

Newcastle, Margaret, Sylvia L. Bowerbank, and Sara H. Mendelson. 2000. Paper Bodies: A Margaret Cavendish Reader. Peterborough: Broadview Press.

Norbrook, David. 1997. Lucy Hutchinson's "elegies" and the Situation of the Republican Woman Writer (with Text). English Literary Renaissance 27: 468-521. [CrossRef]

Norbrook, David. 2003. 'Words More Than Civil': Republican Civility in Lucy Hutchinson's 'the Life of John Hutchinson'. In Early Modern Civil Discourses. Edited by Jennifer Richards. Houndmills, Basingstoke and Hampshire: Palgrave Macmillan.

Patrick, Patricia. 2015. "All That Appears Most Casuall to Us": Fortune, Compassion, and Reason in Lucy Hutchinson's Exploratory Providentialism. Studies in Philology 112: 327-52. [CrossRef]

Pinker, Steven. 2012. The Better Angels of Our Nature: Why Violence Has Declined. New York: Penguin.

Richards, Jennifer. 2003. Early Modern Civil Discourses. Houndmills, Basingstoke and Hampshire: Palgrave Macmillan.

Ross, Sarah. 2015. Women, Poetry, E Politics. New York: Oxford University Press.

Szalavitz, Mia, and Bruce Perry. 2010. Born for Love: Why Empathy Is Essential, and Endangered. New York: HarperCollins.

Walters, Elizabeth. 2013. Gender and Civil War Politics in Margaret Cavendish's "assaulted and Pursued Chastity". Early Modern Women 8: 207-40.

Wheale, Nigel. 2007. Writing and Society: Literacy, Print and Politics in Britain 1590-1660. New York: Routledge. Whitaker, Katie. 2003. Mad Madge: The Extraordinary Life of Margaret Cavendish, Duchess of Newcastle, the First Woman to Live by Her Pen. New York: Basic Books.

Worden, Blair. 2009. The English Civil Wars 1640-1660. London: Weidenfled \& Nicolson.

(C) 2019 by the author. Licensee MDPI, Basel, Switzerland. This article is an open access article distributed under the terms and conditions of the Creative Commons Attribution (CC BY) license (http://creativecommons.org/licenses/by/4.0/). 